\section{Making College Pay Off}

by Adele Scheele. New York: Ballantine Books, 1983. 209 pages, 2.95 (paper)

This book has much to contribute to the total education of a college student. The author alerts the high school and college student to the idea that a college education should be seen as a head start inlo the real world rather than as a time out from the real world. "Making College Pay Off" could well be required reading for every freshman.

As any college placement oflicer can tell you, all too many students wait until the eve of their graduation to seriously consider the relationship of the college curriculum to the job or career that will follow. Too late, says the author, who wants every student to see college as a laboratory or fouryear internship for future employment. To that end each chapter is devoted to ways that different college experiences can help develop skilis needed to be successful in a career that lollows. She equates attitudes and skills that can be developed as a student to those needed in the work force. And she continually stresses that for a college experience to lead to work opportunities, a student cannot be caught in a passive-student trap. "You can't wait for things to happen," says author Scheele, "you must make it happen."

The author's approach is pragmatic, full of how to's. How to set goals, how (ary why) to do more than your share, how to get the recognition you deserve, how to broaden your experiences through extra curricular activities, how to make the most of tests, papers and projects. in one chapter, Dr. Scheele points out that welcome as peer support may be, of far more value are strong monitoring relationships with professors and department heads. Later, she says, if will be your professors, not your peers, who can help you get your first job and if will be your boss, not your fellow em ployees who will get you your promotion. The book concludes with a check list to stimulate the student reader to action, to make opportunities for things to happen during the college years.

"Making College Pay Olf" could serve as an excellent text or required reading in a freshman orientation course. Chapters dealing with everyday experiences in the life of a college student can lead to stimulating class discussions. For instance, where is the fine line between brown-nosing and a positive moniloring relationship with a professor? What are the risks in seeking to be recognized? How does one successfully balance extra curricular activities with the need to earn good grades? What is a potential employer looking for when evaluating a student's college experience?

"Academic learning needs to be integrated with an awareness of how things work in the world" says the author. This book will tell the student reader how this can be accomplished.
Miller, T. E., \& Brickman, S.B. Faculty and Staff Mentoring: A Model for Improving Student Retention and Service. NASPA Journal, 1982, 19 (Winteripp. 23-27.

At Canisius College, a Faculty and Stall Mentoring Program was established to helpnew students become personally involved in campus life and to increase the interaction of students with faculty members and administrators. Fitty-five individuals from the academic disciplines and all phases of administration volunteered to serve as unremunerated mentors in the program. The mentors met with about eight students each in five meetings throughout the academic year. Discussions were led by a student stafl member from the orientation program. About 60 percent of the mentored students regularly attended the meetings.

A1 the end of the first semester, a comparison of the 384 mentored students and the 381 students not selected for the program revealed that the mentored ireshmen were less likely than the other freshmen to receive

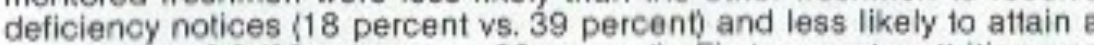
grade below 2.0 (20 percent vs, 33 percent). First-semester attrition was greater among the students not in the program (11 percent) than among those in the program ( 3 percent). At the end of the year, about 20 percent of these in the program ( 3 percent). At the end of the year, about 20 percent of indicating that the program should be extended to all students. 44 ref?Dean of Students, Canisius College.

ireprinted with permission from Higher Education Abstracts - formerhy College Student Personnel Abstracts, Vol, 18, No. 1, ppg. 88\}

Brinkerholf, D.B. \& Sullivan, P.E. Concerns of New Students: A Pretest-Posttest Evaluation of Orientation. Journal of College Student Personnel, 1982, 23(September) pp. 384-390.

At the University of Nebraska (UNL), a 37-item questionnaire on demographic background and level of new-student concern in seven areas (academios, finances, location of facilities and bulldings, university structure, housing, identity, and social relationships) was completed by a systematic random sample of 167 of the 1,764 participants in the 1979 UNL. Summer Orientation Program. The 6-part orientation program was held on orientation day and included a welcome session, seven 20-minute minhsessions, campus tours, a student concerns session, a discussion of academic perspecfives, and housing and health center tours. The questionna re with background items was completed before participation and the ratings items were completed again two weeks after participation.

The results revealed few variations in responses by background characieristics. The students expressed at least moderate concern on almost al items at pretest. Overall levelol concern decreased from pre- to posttest fo all 37 items, and tests revealed significant decreases in concern for all areas except social relationships. The greatest reductions in concern were in location of buildings and facilities, housing, university structure, and academics. Examination of difference scores for each student revealed that more than half of the students had a decrease in concerns, about 30 